\title{
«ШТИРНАЙЦЯТИЙ РІК СУМНИЙ НАСТАВ»: ФОЛЬКЛОРНО- ФІЛОСОФСЬКЕ БАЧЕННЯ «ТРУДНОЇ» ІСТОРІЇ УКРАЇНИ ТА ЇЇ НАРОДУ В ПЕРІОД ПЕРШОЇ ПОЛОВИНИ ХХ СТОЛІТТЯ.
}

(Рецензія на: Кузьменко О. Драматичне буття людини в українському фольклорі: концептуальні форми вираження (період Першої та Другої світових воєн): монографія. Львів: Інститут народознавства НАН України, 2018. 600 с.)

\section{DOI 10.25128/2304-1222.19.48.11}

Оксана Кузьменко своєю монографією «Драматичне буття людини в українському фольклорі: концептуальні форми вираження (період Першої та Другої світових восн)» у наш «постфольклорний» час сказала нове наукове слово, здійснивши дослідження на матеріалах, які бачаться на межі авторського й народного та стосуються першої половини XX століття. Найперше - вона залучила до наукового обігу не тільки тексти «класичних» жанрів необрядового фольклору, але i «“широкоформатні” тексти перехідного типу 3 ознаками індивідуально-фольклорної інтерференції, у композиції яких, як правило, синтезуються елементи різних жанрів: усні автобіографічні оповідання у формі меморатів і фабулатів, самодіяльні віршовані листи, пісні-послання, сучасні усні перекази з історії села про “війну”, про “голодовку”,“про виселення”, що найкраще фокусують колективні ідентифікації, суспільно-громадські та індивідуальні цінності, звичаєві норми та народні стереотипи» (с. 16). Вони, за переконанням дослідниці, мають ознаки «фольклорності», а тому знаходяться у смисловому полі фольклористики. Завдяки цьому джерельна база роботи дуже потужна. Загалом велика кількість джерел та теоретичних праць, використаних у монографії, зумовлена самою темою, метою й методологією дослідження.

Варто також наголосити, що наша гуманітаристика поповнилася загалом вагомою теоретичною працею, в якій авторка по-новому оцінює «різнорідні» явища українського фольклору як «свідомісно-інформативну й текстову цілість»; пропонує інше прочитання необрядових фольклорних текстів; впевнено розширює в українській фольклористиці семантичні обрії терміну «фольклорний концепт» на основі таких глибоко емотивних, екзистенційних для кожного українця понять, як «війна», «ворог», «молитва», «материнство», «туга», «страх» та інших. Ці поняття виступають «постійними інформаційними знаками пам’яті» (В. Буряк) та в 
дослідженні виконують роль словесних екзистенціалів, переростаючи у фольклорні концепти, для розгляду яких авторка виробила власну аналітичну матрицю. Крізь призму праці вони сприймаються як «ключові поняття», що «об’ єктивізують досвід драматичної екзистенції людини» (с. 14), а конкретно - українського етносу в XX столітті.

Смислонаповнення терміна «фольклор» для дослідниці - не лише загальноприйняте «мистецтво народного слова, сукупність різних видів і жанрів народної творчості», але також і «складна система універсальних кодів, які через вербальний текст виявляють світоглядні та ціннісні концепти етносу, а також морально-етичний, естетичний, релігійний, суспільно-історичний, колективний, поколіннєвий, гендерний досвіди людини» (с. 12-13). Через психологічно-емоційну та почуттєву складову фольклору, що концентрується у вербальних текстах, на думку авторки, людина виявляє іманентну здатність «сприймати та пізнавати навколишній світ, усвідомлювати його цінності, виявляти емоції», показувати «своє ставлення до дійсності, до особистого і колективного співжиття» (с . 8).

Варто також відзначити, що в аналізованій монографії використано не тільки загальновідомі методи дослідження, але й бінарні (як структурно-семантичний, icторико-типологічний, порівняльно-типологічний) та нові у філології поєднання і методичні прийоми (як концептуальний, статистичний, методи із залученням структурно-функціонального й психологічного аналізу), що для такого типу роботи виявилися надзвичайно ефективними. Інтердисциплінарність у підходах до студій, за визначенням самої О. Кузьменко, вирішує, окрім фольклористичних, ще й низку питань філософсько-культурологічних, намагаючись «виявити основні тенденції сучасних гуманітарних наук у вивченні колективно-історичного досвіду та універсальних кодів культури» (с. 15). Це спонукає думати, що зазначена праця є результатом багаторічного дослідництва, оскільки у своїх студіях авторка, спираючись на досвід вітчизняних та зарубіжних учених, звернулася до різноманітних аналітичних методологій, наукових підходів, використала дані усної та соціальної історії, культурології, етнопсихології, наратології, текстології та інших гуманітарних галузей, синтезувала їх, що дозволило їй інтегрувати й проаналізувати стосовно поставленої мети «неоднорідні форми комунікації людей». 
Власне, можна стверджувати, що Оксана Кузьменко здійснила вельми вдалу спробу крізь призму уснословесних текстів, які зберігаються в народній пам'яті, осягнути особистісну екзистенцію людини, пов'язану із драматичними моментами іiї родинного та суспільного буття, які породжені Першою та Другою світовими війнами й трагічними подіями, що, хоч і $є$ наслідковими, але не менш трагічно-значущі для самого народу (голодомори, територіальні перерозподіли, депортації й т. ін.).

У першому розділі «Джерела та історіографія», який містить ряд підрозділів, вона представила об’ єктивний аналіз джерел «у складному співвідношенні того, що насправді записане і того, що було досі опубліковане» (с. 20), включаючи малодоступні архівні матеріали, а також зовсім недавно записані та опубліковані. У пункті 1.1.1. дослідниця звертає увагу на те, що основними дійовими особами нарацій та народних пісень періоду Першої світової війни є насамперед ії жертви: фронтовик, дівчина-покритка, жінка-удова, діти-сироти, згорьована мати, син якої загинув на полі бою чи повернувся калікою. На жаль, як пише авторка, багато таких творів «ще й досі перебувають на маргінесі збирацьких та дослідницьких зацікавлень» (с. 23), особливо це стосується окремих авторських новотворів різної тематики (родинної, суспільної, хронікальної, сатиричної-анекдотичної і т. д.) та жанрів «з виразними ознаками фольклорності» (с. 24). Важливою бачиться думка авторки про те, що «знаковим явищем для фольклоротворчої атмосфери Першої світової війни стала потужна індивідуальна авторська та анонімна поетична творчість (можна додати: й прозова, про що у монографії йдеться нижче, де особливо цікаво аналізуються оповідання-меморати, які часто ставали основою для авторських творів Ж. Янковська), у якій відобразилося співвідношення колективного й індивідуального в семантизації катастрофічної дійсності» (с. 26).

Загалом у чотирьох пунктах підрозділу 1.1. («Джерельна база: архівні колекції, публікації, сучасні записи в оптиці жанрів та автентики») охоплено надзвичайно великий корпус (що дуже вражає!) різноманітних фольклорних та «фольклоризованих» авторських джерел, що стосуються заявленого у темі періоду дослідження. Вони чітко структуровані й класифіковані, що є вельми корисним для майбутніх дослідників. Мало того, останнім в аналітичному ряді представлено власні авторські польові записи, зроблені О. Кузьменко у декількох областях України (158 
селах!), які також узагальнено, систематизовано й проаналізовано. А це велика, гідна неабиякої поваги праця.

Наступним важливим кроком дослідження Оксани Кузьменко стало визначення етапів вивчення фольклору періоду двох світових війн та аналіз праць, що їх репрезентують. Загалом авторка притримується поділу на дорадянський, радянський та пострадянський періоди. У кожній наступній частині підрозділу 1.2. вона репрезентує праці вчених, які фіксували та аналізували народні твори, що стосувалися погляду на війну як на суспільну трагедію. За цими творами та дослідженнями бачимо, як із настанням війни змінюються пріоритети соціуму, переакцентовуються цінності, набирають значимості психологічно-емоційні аспекти життя, виникають фольклорні твори, у яких на перше місце виходять поняття «туга», «смуток», «ворог», «рідна земля», «неволя», «смерть», «могила»і т. п., а також антиномія «війна - мир», що співзвучні із душевним станом людей, які спільно переживають драматичні події. Разом з тим, у праці звертається увага на панівну ідеологію у той чи інший період та її вплив на суспільну думку. Дуже цікаво спостерігати, як, всупереч ідеологічним настановам, фольклорні твори відображають неупосліджений погляд на ті чи інші події, що часто, наприклад, за радянських часів, ставало причиною покарання його виконавців. При цьому наративні твори насичувалися героїкою, набирали ознак легенди, переказу, а поетичні - часто інтенціювали до голосінь, плачів, сумних ліричних пісень.

За переконанням дослідниці, «на початку ХХІстоліття змінив свій напрямок вектор наукового осмислення Другої світової війни, маркованої в радянському (нерідко і в пострадянському) просторі як “Велика Вітчизняна війна”» (с. 119). Праці вчених пострадянського періоду, як бачимо із роботи, позначені розвінчуванням «неправди», відкриттям нових народних та авторських творів, які за радянських часів іноді виконувати боялися, та встановленням істинно-наукових пріоритетів у дослідженні уснословесних та близьких до них авторських текстів, при цьому враховано культурологічний та соціологічний аспекти.

Ще однією рисою, на яку небезпідставно звертають увагу сучасні дослідники, як пише Оксана Кузьменко, є регіональність «як одна з особливостей цього фольклору», яка «передбачає вивчення його специфіки на різних рівнях: семантики, син- 
тактики і прагматики. Учені продовжують досліджувати генеалогічні складові, цикли, тематику і мотивний фонд пісенних творів, більшість із яких виникла одразу після завершення світової війни як результат другої хвилі упокорення західних українців та агресивного наступу комуністичної влади на потужний військовий та національно-патріотичний рух опору» (с. 122-123).

Другий розділ рецензованої монографії «Теоретико-методологічні засади дослідження драматичної екзистенції у фольклорі» також структурно розгалужений та має два підрозділи. У першому підрозділі розглядається усний народний текст як форма концептуалізації історичного досвіду, розглянуто специфіку досліджень та методологічних підходів у цьому напрямку. Осмислюючи ліричне та епічне начала фольклорного тексту, дослідниця звертається до періоду романтизму, часу, коли українська фольклористика поставала як наука,і пише про те, що вже перші дослідники народної творчості, як М. Максимович, І. Срезневський, О. Бодянський, М. Сумцов, О. Потебня, М. Костомаров, П. Куліш, а пізніше - М. Драгоманов, I. Франко, Ф. Колесса та багато інших «зрозуміли: емоційне,чуттєве, ментальнеможе бути предметом мистецтва, а народна пісня є одниміз найкращих його виявів» (c. 133). Тому й предметом найперших їхніх фольклорних записів, публікацій і фольклористичних студій стали саме пісні, в яких екзистенції туги, смутку, любові, сподівання та інші відображені й звучать дуже виразно.

Дуже предметними у цьому розділі є розмежування авторкою текстів «усноісторичних» та «фольклорних», межа між якими є досить умовна, інколи мотивно та змістовно-тематично вони перетинаються, стосовно чого Оксана Кузьменко зазначила: «Зваживши на сказане, зазначимо, що усноісторичні та фольклористичні дослідження мають багато спільного. Їх об'єднує структурне розуміння тексту, у якому наявні певні стійкі елементи композиції з визначеними функціями» (с. 162). Окремі ж відмінності дослідниця вбачає у цільових, чітко оформлених за питаннями інтерв'ю, вибором та компонуванням інформації в усних історичних наративах, які менш емоційно наснажені, тоді як подібний сюжет у записах фольклористів може бути чисто випадковим, проте психологічно напруженим, «пережитим» $\mathrm{i}$, відповідно, містить менше точного фактологічного, датованого й номінаційного матеріалу. Сама ж Оксана Кузьменко ці відмінності означила так: «Перша відмінність - прагматичний бік суб'єктивного досвіду людини, їі ідентичності та 
самопрезентації, що є важливим для усних істориків. У той же час для фольклористів цікавою є поетика, художній зміст, багатозначність смислу вираження загальнотипового суспільного досвіду, об’єктивованого через фольклорні концепти; жанрова форма тексту, мовні засоби його відтворення, які є традиційними для фольклорного словника певного колективу.

Друга відмінність - це ставлення до суб’єкта-оповідача. Усні історики шукають “надійного” інформатора, уякого багатий, “неповторний” життєвий досвід. Фольклористи натомість звертають насамперед увагу на інформатора-виконавця, який наділений “артистичним інстинктом”» (с. 164).

Не оминула увагою авторка монографії й семіотично-лінгвістичний аспект аналізованої проблеми, оскільки для того, аби предметно говорити про параметри поняття «фольклорний концепт» загалом і семантичні та смислові концепти туги, Батьківщини, матері, рідної землі і т. п. зокрема, потрібно було виходити із поняття «слово-концепт», яке потрібно розглядати насамперед у символічній та лінгвістичній площині. Вивести логічну парадигму цих понять допомогло і звернення до семантики етнологічних термінів «ментальність» та «фольклорна картина світу», що ще раз довело інтердисциплінарний характер самого дослідження.

В результаті структурно-семантичного, історико-типологічного, мотивемного аналізу українських фольклорних текстів про світові війни авторкою було виведено дванадцять найбільш типових фольклорних концептів, які об'єднано в чотири структурно-семантичні групи: універсально-екзистенційні, емотивні, персонажні, просторові, які Оксана Кузьменко візуалізувала, створивши семіотичну модель відображення досвіду семантичної екзистенції людини у фольклорі періоду двох світових війн (с. 187).

У підрозділі 2.2. вибудувано мотивемно-мотивну парадигму як основу кодування буттєвого досвіду у фольклорі. Дуже доказово й підставно, на конкретних прикладах схем та моделей, спираючись на фольклорні тексти, дослідниця простежує, як мотив поступово переростає у концепт, досить позірно подає методику укладання мотивемно-мотивного покажчика, яка і стала основою для виокремлення конкретних фольклорних концептів. Водночас введено до фольклористичного обігу поняття «епізод», що більше використовувалося у літературознавстві, але в цьому випадку виступає як «структурна модель пам’яті фольклорних наративів», а 
відповідно знаходиться на початку парадигми, що приводить до формування концепту: здійснює безпосередній вплив на формування мотиву, а відтак - і конкретного фольклорного концепту.

У наступних чотирьох розділах Оксана Кузьменко згідно із чотирма сформованими і названими вище структурно-семантичними групами детально аналізує зазначені дванадцять фольклорних концептів, демонструючи свої доведення конкретними прикладами, вдаючись до вельми цікавого текстологічного аналізу народних наративів та необрядової лірики. Як не дивно, але іноді навіть через покоління в родинах живуть і передаються «знаки пам'яті» про передчуття, передбачення, прикмети, пережиття наслідків війни. У кожного покоління до них різне ставлення, яке дуже відрізняється у представників соціуму (зокрема, серед сільського населення), які пережили самі війну, у яких воювали/загинули на війні батьки, діди (третє покоління)і в яких це почуття позбавлене «безпосереднього дотику» до покоління, яке пережило війну.

У роботі крізь призму фольклорних наративів та поетичних творів розглядаються різноманітні відтінки почуттів, емоційних станів, які переживають представники різних соціальних станів на всіх етапах війни. Тому виокремлені концепти аналізуються у сув'язі з тими образами, які їх супроводжують (наприклад, образ кулі, страдника, героя, представника тієї чи іншої етнографічної групи чи етнічної меншини та ін.). Із прикладових матеріалів можемо простежити, як подібно і разом 3 тим по-різному сприймали одні й ті ж драматичні події в регіонах України, що пов'язано із їхнім геополітичним розташуванням й тим, наскільки глибоко торкнулися ті чи інші події регіону, в якому були записані тексти. Особливо позірні відмінності простежуються на західноукраїнських територіях. Аналізовані крізь призу розповідей і творів самого народу на рівні відстеження психологічно-емоційного їх сприйняття, ці події бачаться насправді стереоскопічно навіть на відстані майже століття.

Насправді монографію Оксани Кузьменко можна довго характеризувати й аналізувати, можна сказати ще багато добрих слів на адресу авторки, але найперше - вітати, настільки багато «важких» проблем у ній порушено, які довго комплексно ніхто не наважувався аналізувати. Вражає широта і глибина осягнення фактологічного матеріалу, джерел, теоретична база. Зважаючи на це, праця, сподіваємося, 
стане потужним історико-методологічним, теоретичним та джерельним підгрунтям не тільки для фольклористів, але й корисною в етнології, історії, літературознавстві, соціології, етнокультурології, етнофілософії, етнопсихології та інших гуманітарних галузях.

Ж. О. Янковська

доктор філологічних наук, доцент, професор кафедри культурології та філософії

Національного університету «Острозька академія» 